\title{
Sinema ve Mekân İlişkisi Açısından Bilimkurgu Filmlerine Bir Bakış
}

\section{ÖZ}

\author{
Elif Hicret EK BEKTAŞ ${ }^{1 *}$
}

Sinema günümüzde yedinci sanat dalı olarak bilinmektedir. Var olmayan mekanları izleyiciyle buluşturabilmesi veya var olan mekanları farklı bir şekilde yansıtabilmesi tasarımcı kimliği altında bulunan insanların dikkatini çekmektedir. Mimarlık disiplini ile en iç içe olan sinema türü bilimkurgu olarak göze çarpmaktadır. Bu çalışmada sinema ve mekân ilişkisi bilimkurgu filmleri üzerinden incelenmiştir. Çalışma kapsamında; Tron efsanesi, Başlangıç, Azınlık Raporu, Açlık Oyunları filmleri irdelenmiştir. Seçilen filmler farklı hipotezlere cevap veren senaryolar üzerinden seçilmiştir. Konu ile ilgili literatür taramaları yapıldıktan sonra filmler izlenmiş ve bu filmler üç başlık altında incelenmiştir. Daha sonra sinemanın iç mekân tasarımına etkisi incelenen filmlerden iki tanesi üzerinden ele alınmıştır. Yapılan bu çalışmanın yedinci sanat olarak tanımlanan sinema ve mekânın tasarımına yönelik disiplinler arasındaki ilişkiyi araştıran çalışmalar için kaynak oluşturması hedeflenmiştir.

Anahtar Kelimeler: Sinema, Mekân, Bilimkurgu.

\section{A Look at Science Fiction Movies in Terms of Cinema Space}

\begin{abstract}
Cinema is now known as the seventh art branch. The ability to meet non-existent venues with spectators, or to reflect existing spaces in a different way, attracts the attention of people under the identity of the designers. The type of cinema that is the most intertwined with architecture discipline is striking as a science fiction. In this study, cinema and space relation were studied through science fiction films. Scope of work; Tron myths, Beginning, Minority Report, Hunger Games. Selected films were selected through scenarios that responded to different hypotheses. After a literature searches on the subject, films have been watched and have been analysed under three headings. Later on, the influence of the cinema on the interior design was discussed through two of the examined films. The purpose of this study will be the source for studies investigating the relationship between disciplines for the design of cinema and space, which is defined as seventh art.
\end{abstract}

Keywords: Cinema, Space, Science Fiction.

\section{GíRiş}

Sinema (cinéma) sözcüğü, sinematografi (cinématographie) sözcüğünden kısaltılmıştır. Lumière Kardeşler kendi buluşları olan aygıta sinematograf (cinématographe) adını vermişlerdir. Yunanca 'kineına, -atos = devinim (hareket)' ile 'graphein = yazmak' sözcüklerinden türetilen sinematograf, 'devinimi yazan, devinimi saptayan' anlamına; sinematografi de 'devinimi yazma, saptama' anlamına geliyordu. Yalnız Lumière Kardeşler değil, sinemanın buluşlar çağında çeşitli alıcıları (kameraları) yapanlar da bunlara hep 'devinim', 'canlılık', 'yaşam' kavramlarıyla ilgili adlar vermişlerdi. Çünkü yeni buluşun en belirgin özelliği, devinimi, yaşamı olduğu gibi yansıtabilmesiydi. Nitekim günümüzde çok yaygın olan, hemen her ülkede kullanılan sinema sözcüğünün yanı sıra Birleşik Amerika'da çok kullanılan 'motion picture, moving picture (ve bunun

\footnotetext{
${ }^{1}$ Kocaeli Üniversitesi İç Mimarlık Anabilim Dalı

* Illgili yazar / Corresponding author: elifhicretek@gmail.com

Gönderim tarihi: 21.05.2017
}

Kabul tarihi: 08.12.2017 
kısaltması 'movie') = devinimli resim' de yine aynı tutumu yansıtmaktadır (Özön,1956, s.3).

Bu çalışmada, sinema-mekân ilişkisi üzerinden; sinemanın, teknolojinin en çok kullanıldığı türlerinden biri olan bilimkurgu filmleri üzerinde durulmuştur. Çalışmada Açelya Allmer 'in eseri "Sinemekan-Sinemada Mimarlık" kitabında filmleri incelemiş olduğu başlıklardan üçü, 2000'li yıllarda yapılmış olan bilimkurgu filmleri üzerinden incelenmiştir. Bu başlıklar aşağıda verilmiştir:

1. Sinema mekânı eleştirir,

2. Sinema mekânı düşletir,

3. Sinema mekânı temsil eder.

Bu çalışmada amaçlanan, sinema ve mekân ilişkisinin yukarıda belirtilen başlıklar altında 2000'li yıllarda yayınlanmış olan bilimkurgu filmleri üzerinden incelenmesidir. "Sinema mekânı eleştirir" başlığında; Tron Efsanesi filmi mekânsal sınırlamaları eleştirdiği düşünüldüğü için seçilmiştir; "sinema mekânı düşletir" başlığında; Başlangıç filmi var olmayan mekanları kurguladığı için ve Azınlık Raporu filmi gelecek kurgusunda mekanları incelediği için; "sinema mekânı temsil eder" başlığı altında; Açlık Oyunları filmi kurguda var olan iki toplumsal kesimi başarılı bir şekilde temsil ettiği için seçilmiştir. Çalışma yapılırken izlenen yöntem literatür taramasından edinilen bilgiler ve izlenen filmlerde yapılmış olan gözlemlerden yararlanıımasıdır.

\section{SINEMA VE MEKÂN İLIŞKISi}

Aristo, mekânı "nesnelerin birlikteliği" olarak ya da başka bir deyişle, "en geniş anlamından en darına kadar birbirini kapsayan tüm olguların birlikteliğinin bir başarıs" olarak görmektedir. Dolayısıyla varoluşun çeşitli temsillerini üreten bir sanat dalı olan sinema, mimarlık ile ilişkisini varoluşuyla birlikte hem maddesel hem de ruhsal yönüyle kaçınılmaz olarak kurmuştur. Bu nedenle; "mekân" kavramı, çevresi ve diğer mekânsal olgular ile etkileşimi ve bu etkileşimin deneyimsel sonuçları yadsınarak tartışılamaz (Beşışık, 2013, s. 1).

Lefebvre'e (1991) göre "mekân okunmadan önce, yaşanmak üzere üretilir". Mekânın yeniden üretiminde yaşanan deneyim içinde barındırdığı eksiklik hissi ile devinim yaratır. Marcus'a göre ise yaşanan mekânın üretimi söylem (soyut + somut üretim) dışı olduğu kadar söylemseldir. Somut, fiziksel bir üretim olduğu kadar soyut ve zihinseldir. Mekân üretiminin soyut- somut söylemsel nitelik barındırması; mekânın soyut ve sosyal eşiği olabilir. Aldo Van Eyck (1962) çoklu okuma ve anlamlandırma olarak 'ara- uzam' gerçekliğini tanımlar. Bu ara - uzam olma, belirsizlik, mesafeli duruş; mekânın sürekli yeniden üretimine yol açar. Zihinsel ve fiziksel müdahaleyle mekân her 'an' değişebilir. (Topal,2013, s. 21)

Sinema hiç gitmediğimiz yerleri deneyimleme fırsatı verir, bu yönüyle mimari kültüre ve eğitime katkıda bulunur ve mekânsal deneyim zenginliği yaratır. Seçkin Kutucu 'ya göre sinema hafıza ile; mimarlık ise tarih ile benzerlik kurar. Sinema imgeleri sosyal hayatımızı etkiler. Bu, filmlerle tanımlanmış zaman ve mekân kavramlarının insan zihninde ki görsel hafıza tarafından deneyimlenmesi ile gerçekleşir. Örneğin hiç Paris'e gitmemiş biri bile bir filmde Eiffel Kulesi'ni, Şanzelizeyi ya da bir ucundaki Zafer Takını gördüğünde burasının Paris olduğunu bilir. Çünkü daha önce bu landmarklar ve kentin dokusu, görsel deneyimler halinde hafızamıza kaydolmuştur. Böylelikle hiç gitmediğimiz kentlerle ilgili görsel anılarımız olur (Beşışık,2013, s. 13). 
Sinema ve mimarlık ilişkisinin, sadece estetik yaklaşımlar ve set tasarımları bakımından değil, filmlerin mimari eleştiriye kattıkları ve modern çevreyi olduğu kadar tarihi çevreyi de farklı bakış açılarıyla gösterme güçleri yönünden anlaşılmaya çalışılması, film söylemlerinin tarih, sosyoloji gibi alanlarda meşruiyet kazanması ile bağlantılı olarak düşünülebilir. Televizyon ve bilgisayar gibi teknolojik araçların ortaya çıkması, görsel kültür ürünlerinin dünya üzerindeki dolaşımını hızlandırmış ve arttırmış, bir kitle iletişim aracı olan sinema ile birlikte bu görsel kültür kaynakları insanların yaşam biçimlerini ve dünyayı algılamalarını etkilemiştir (Kale,2004, s. 4).

Filmlerde bazen var olmayan şehirlerin, ülkelerin tasarlanabildiğini görmekteyiz; bu da sinema ve mimarlığın kesiştiği noktalardan birisini oluşturmaktadır. Sinema, mekân tasarımcısı için bir test sahasıdır. Gündelik hayatların sorunlarından uzakta mekanlar üretebildiği bir alandır.

\section{BILIMKURGU FILMLERI VE MEKÂN İLIŞKISi}

Sanatsal bir kavramı ifade eden tür sözcüğü dilimizde, Fransızca kökenli genre sözcüğünün karşılığı olarak kullanılmaktadır. Aslında genre daha çok cins- "aralarında benzer, ortak özellikler bulunan varlık ve nesnelerin topluluğu"- anlamına gelmektedir. Ancak sanat alanına ilişkin bir terim olan genre için türün kullanılması daha doğrudur. Zaten tür, Türk Dil Kurumu Güncel Türkçe sözlüğünde:" İçerik, biçim ve amaç yönünden özellik gösteren bir sanat çeşidi "olarak tanımlanmaktadır. Dolayısıyla tür, çeşitli sanat dallarındaki yapıtların gruplar halinde toplanmasının sonucu olarak, bu grupları belirtmek için kullanılan bir kavramdır ve öncelikle sınıflandırma çabalarıyla ilgilidir (Abisel, 1995, s. 13).

Sinemada türler, kullanılan teknik, hitap ettiği kesim ve işlediği konu olarak ayrılmaktadır. Konularına göre türler: korku, aksiyon, komedi, western, bilim kurgu, dram, belgesel vb. film türlerini sayabiliriz. Hitap ettiği kesime örnek olarak çocuk filmi, kadın filmi, aile filmlerini örnek verebiliriz. Kullanılan tekniklere göre sinema türleri için ise siyah-beyaz, üç boyutlu filmler ve sessiz sinema filmlerini söyleyebiliriz.

Bilimkurgu, Amis'in (1960) yaptığı tanıma göre, bildiğimiz dünyada var olmayan, ama bilim ve teknolojideki gerçek ya da hayali yenilikler üzerine temellendirilmiş durumları konu eden öyküsel bir düzyazı türüdür. Van Shaik'e (1999) göre ise bilimkurgu, tekil bir vizyon tarafından hayal edilmiş gelecek öngörüsüdür. Bilimkurguyu pek çok farklı biçimde tanımlamak mümkündür. Fakat ismi koruduğumuz sürece, insanın kendisini ve çevresini gözlem, hipotez ve deney yoluyla anlayabilme aracı olan bilim ile ilişkisi konusunda ısrarcı olmak mantıklıdır. Bilimkurgu, bilimsel rasyonalizm, zamanın çizgiselliği ve tarihsel değişimin kaçınılmazlığından yola çıkarak kökleri günümüzde bulunan eleştirel gelecek senaryoları üretir. Diğer bir deyişle bilimkurgu özünde, günümüze özgü birtakım şeylerin (en azından bir şeyin) gelecekte radikal biçimde değişeceği varsayımının yattığı deneysel bir yabancılaştırma sanatıdır. Bilimkurgu sanatçısı, çağına ait toplumsal, ideolojik, etik bilimsel tartışmaları başka bir zaman ve fiziksel çerçeveye taşıyarak, bu tartışmaların tahmin edilen sonuçlarını hipotetik biçimde göstermeye çalışır (Özen, 2006, s. 7).

Bilimkurgu Türk Dil Kurumu Güncel Türkçe Sözlüğü 'ne göre çağdaş bilim verileriyle düş gücünden oluşan (film, roman vb.) olarak tanımlanmaktadır. Bu tanım düşünüldüğünde genelde gelecekle ilgili filmler akla gelmektedir. Bilimkurgu filmleri bilim ve hayal gücünün birleşmesinden oluşmaktadır. Bu da bize var olmayan mekanları kurgulayıp film yapma olanağı sunmaktadır. Mimarlık alanıyla kesişim gösterdiği en önemli konulardan birisi var olmayan mekanları kurgulayıp sunmasıdır. Bilimkurgu filmlerinde çeşitli sorulara çeşitli hipotezlerle yanıt verilmeye çalışılmıştır. Bu 
Sinema ve Mekân İlişkisi Açısından Bilimkurgu Filmlerine Bir Bakış

A Look At Science Fiction Movies İn Terms Of Cinema Space

sorulara yüzyıllardan beri insanın aklını kurcalayan "Evrende yalnız mıyız?", "Gelecekte bizi nasıl bir dünya bekliyor?", gibi sorulara yanıtlar aranırken zaman ve mekân kavramlarının da çeşitli şekillerde incelendiğini görmekteyiz. Günümüzde bilimkurgu filmlerini şekillendiren en önemli sorulardan birisi de gelişen teknolojinin ileride nasıl bir hal alacağı ve yaşantımızı ne şekilde etkileyeceğidir. Çalışmada yer verilen filmler farklı kurgulara birer örnek niteliğindedir.

Mekân, mimarlık-sinema arakesitinde yer alan ve her iki disiplinin de temelini oluşturan bir kavramdır. Sinema için bir oyuncu kadar etkili sayılabilecek sinemasal mekân, mimarlıkta insan yaşamını örgütleyen ve onu anlamlandıran bir unsur olduğu görülmektedir. Diğer türlerden farklı olarak bilimkurgu sineması, mekân tasvirlerinin günümüzden radikal bir şekilde farklılaşıı̆ı unsurlara yer veren bir sinema türüdür (Ayyıldız ve Müştak, 2016, s. 1).

Bilim kurgu filmleri var olmayan mekanları sunmaları veya ileri teknolojiyi işlemeleri bakımından yenilikçi filmler arasında sayılabilmektedir. Yenilikçi filmler, tarz ve biçimleri sayesinde seyircilere daha iyi hayat tahayyülleri sunabildikleri gibi günümüzle ilgili eleştirel düşünceler de ortaya koyabilir veya insan varoluşuna iliş̧in felsefi aydınlanma da sağlayabilirler. Filmlerde seyircilerin mevcut hayat ve zamanlarının sınırlarını aşarak yeni görme, yaşama ve varoluş tarzları tasavvur etmelerini sağlayacak ütopyacı bir boyut potansiyel olarak vardır. Filmlerdeki daha iyi bir dünyaya dair idealize görüşler ideolojik haleler sunabilir. Bu görüşler eleştirel bir biçimde deşifre edildiğinde kendi döneminin ideolojik sorunsallarına ve mücadelelerine ışık tutabilir (Kellner, 2011, s. 35). Teknolojinin gelişmesi; insanoğlunun deneyimlerinin ve bilgi sahibi olduğu yeniliklerin artmasına sebep olmakta ve böylelikle bilim kurgunun da kendine yeni öyküler üretebildiği görülmektedir. Çünkü elde olan verilerle bir sonraki olabilir olanlar düşünülmekte ve bilim kurgu metninin konusunu geliştirmektedir (Özbanazı,2004, s. 50).

\title{
3.1 Sinema Mekânı Eleştirir - Tron Efsanesi Filmi
}

\begin{tabular}{|l|l|}
\hline \multicolumn{2}{|l|}{ Tron Efsanesi / Tron: legacy } \\
\hline Yönetmen: & Joseph Kosinski \\
\hline Senaryo: & Edward Kitsis, Adam Horowitz, Steven Lisberger, Richard Jefferies \\
\hline Oyuncular: & $\begin{array}{l}\text { Olivia Wilde, Cillian Murphy, Michael Sheen, Jeff Bridges, Garrett } \\
\text { Hedlund }\end{array}$ \\
\hline Türü: & Bilimkurgu, Aksiyon, Macera \\
\hline Yapımcı: & Steven Spielberg, Steven Lisberger \\
\hline Yapım yilı ve yeri: & 2010, ABD \\
\hline
\end{tabular}

Tablo 1 Tron Efsanesi Filmi Hakkında Bilgiler

\begin{abstract}
1982'de, yüzde yüz elektronik çekimle ve video trükajlarıyla yapılma ilk filmler olan, ünlü Aristocats ve Tron piyasaya çıkar. Bilgi işlemciler bizleri o tarihten beri, kamera ya da gerçek nesneler kullanılmaksızın matematik modellerden yola çıkarak film yapabilen, dekor ve oyuncu yaratabilen bilgisayarların oluşturduğu bir estetiğe alıştırmaya çalışmaktadırlar (Betton, 1986, s. 97).
\end{abstract}

Tron (Steven Lisberger, 1982) filmi, gösterime girdiği dönemde, diğer bilimkurgu filmleriyle karşılaştırıldığında farklı bir anlam ifade etmektedir. Scott Bukatman (1993, 215-216), Tron'u, oluşturduğu dünya ve tahayyül ettiği zaman-mekân ilişkisiyle ilgili olarak farklı bir konuma yerleştirmektedir. Tron, diğer bilimkurgu filmlerinin aksine ne olumlu ne de olumsuz bir gelecek sunmaktadır. Tron, tamamen başka bir mekânzamanda kendi dünyasını oluşturur ve bu dünya ne gelecektedir ne de geçmiştedir. Burası alternatif bir dünyadır. Tron'un, on altı dakikası dışında tamamen bilgisayar 
ortamında üretilen ilk ticari film olarak adlandıran bu katman, bu nedenle filmin tüm görsel öğelerinin; derinlik, ışık, gölge, hareket ve efektlerin, gerçek kameradan bağımsız üretildiğini vurgular. Film sanal ortamda geçtiği için, kamera da sanallaşarak, gerçek alanda kameranın hareket yeteneklerinin ötesine geçmektedir (Çalışkan, 2013, s. 94).

Filmin başlangıcında 1989 yılındaki bir olaydan bahsedilmektedir. Neresi olduğu belirtilmeyen bir şehir karşımıza çıkmaktadır. Daha sonra Sam Flynn karakterinin büyümüş bir halde yüksek binaların bulunduğu bir şehirde motosikletiyle gezdiği görülmektedir. Sahip oldukları ENCOM şirketinin binası ise neon ışıklarıyla aydınlatılmaktadır. Sam Flynn'ın ziyaret ettiği atari salonu eski bir görünüme sahiptir. $\mathrm{Bu}$ eski atari salonunda kullanılan teknoloji ise ileri seviyededir. Sam Flynn sisteme girmeye çalıştığı sırada sistem düşündüğünden farklı bir şekilde çalışarak onu farklı bir boyuta ışınlamaktadır. Işınlandığı dijital dünyada cam duvarlar ve zeminler göze çarpmaktadır (Fot. 1).

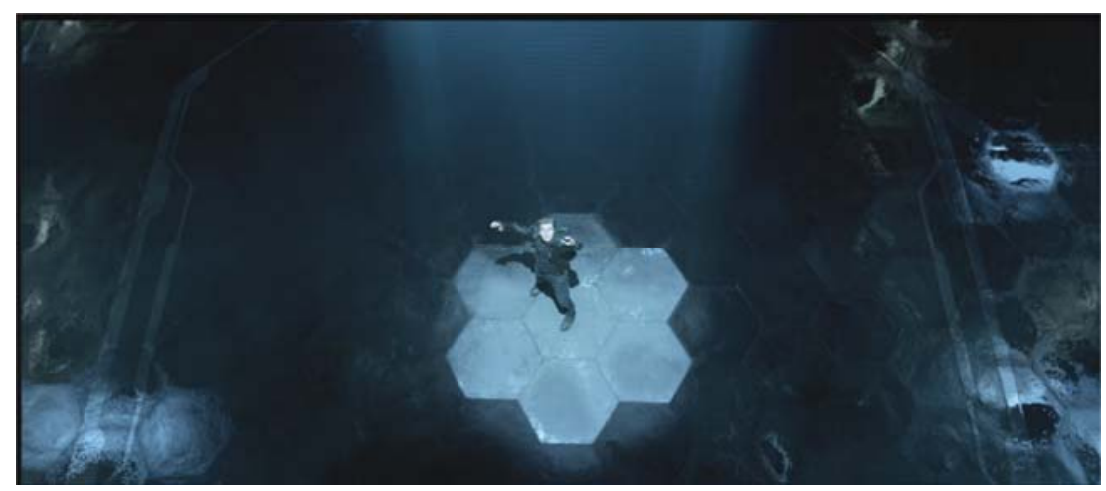

Fotoğraf 1: Sam Flynn'ın Giriş Yapmış Olduğu Dijital Dünya Girişi

Dijital dünyada göze çarpan materyaller metal, cam ve deridir. Gökyüzü bulunmamaktadır. Mekânda sonsuzluk hissinin verilmeye çalışıldığı gözlemlenmiştir. Dijital dünyada sürekli devam eden parlak neon ışıkları göze çarpmaktadır. Materyal olarak camın kullanılması mekanları görünür kılmaktadır (Fot.2).

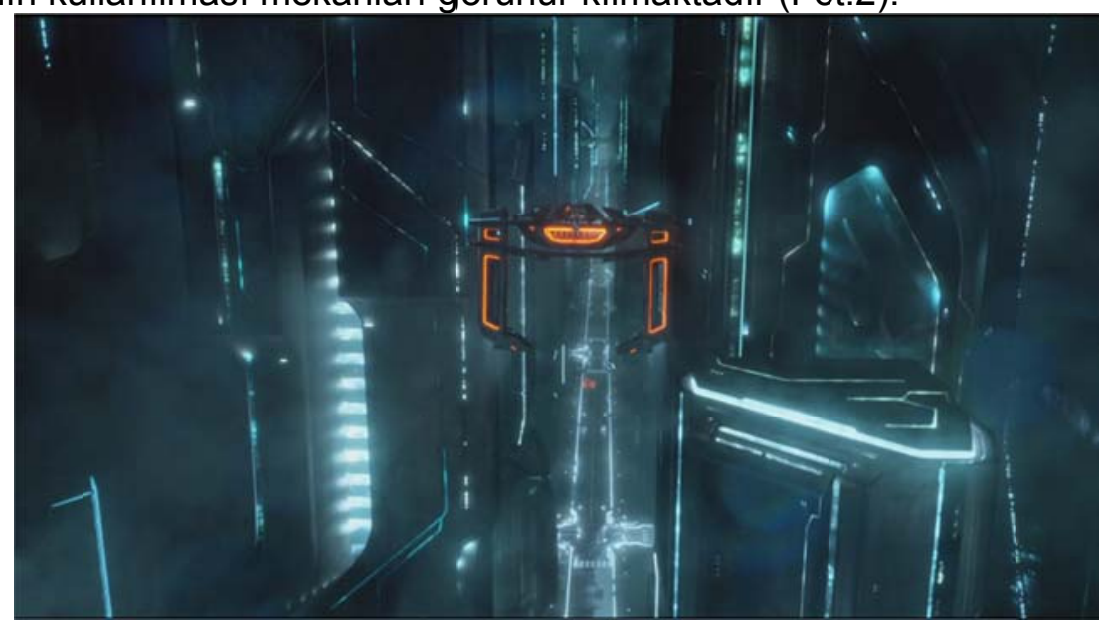

Fotoğraf 1 Dijital Dünya'dan Bir Görünüm

Dijital dünyada babasının yaşadığı mekânda ise beyaz rengin hâkim olduğu görülmektedir. Mekânda kitaplar da göze çarpmakta, mekânın bir kayalığın içine konumlandırıldığı düşünülmektedir (Fot. 3-4). 


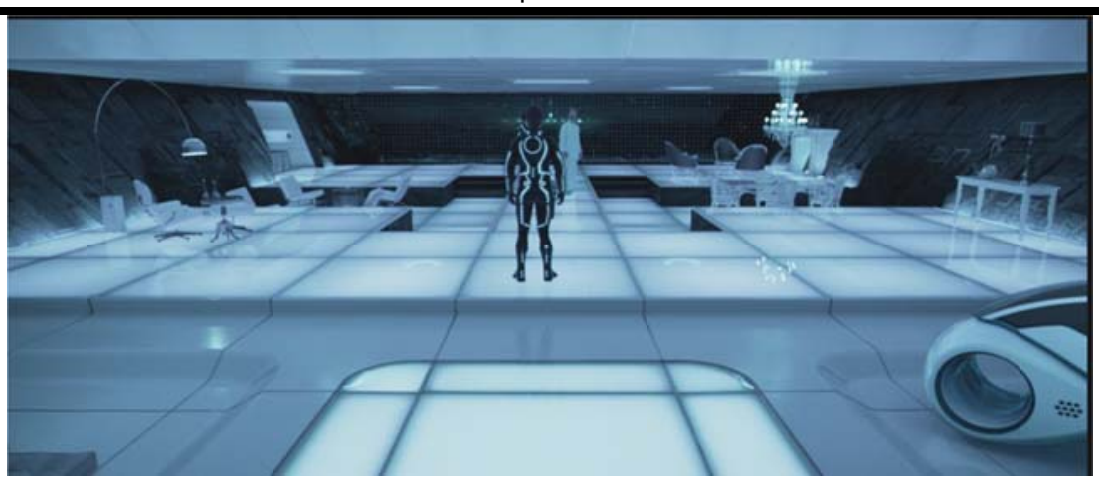

Fotoğraf 2: Dijital Dünyada Kevin Flynn'ın Evinden Bir Görünüm

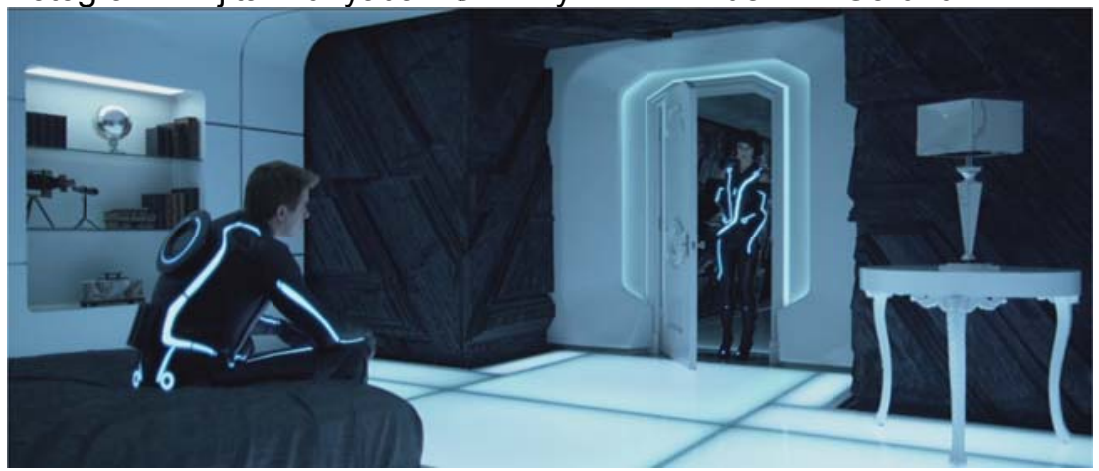

Fotoğraf 3: Kevin Flynn'ın Evinin Dıştan Görünümü

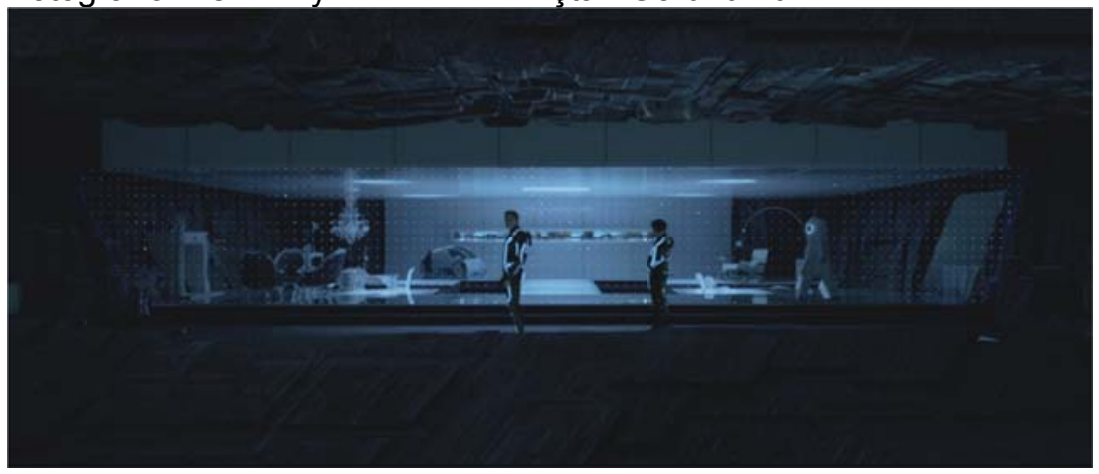

Fotoğraf 4: Sam Flynn'ın Yatak Odasından Bir Görünüm

\subsection{Sinema Mekânı Düşletir:}

Sinema insan yaşamını her türlü boyutuyla ele alan, organik olarak tanımlanabilecek kurguların görsel bir anlatımıdır. Sinemanın görsellik üzerine kurulu olması, yaşamdan kesitler sunuşu, insanı anlatan ve insanla şekillenen bir yapısının oluşu, bu disiplini mekâna muhtaç hale getirmektedir. Ortaya çıkan ürünün iki boyutluluğu bu ihtiyacı köreltmez; aksine film, zamanla birlikte dört boyutu bulunan bir düşünme sistematiğinin bir sonudur: Kaplayan ve kapsayan mekân, mekânı kullanan insan ve insanla mekân arasındaki ilişki ve bu ilişkiyi de kaplayan zaman olduğu görülmektedir. Senaryo karakterler ve karakterlere ait eylemlerle birlikte karakterin sahip ya da ait olduğu mekanlar ve mekânların karakterini de kapsamaktadır. Bir filmde karakterler kadar mekanların da oyuncu olduğu gözlemlenmektedir. Bu yüzden sinema ve mimarlık arasında yadsınamaz bir ilişkinin mevcut olduğu düşünülmektedir. Sinemacı bilinçli ya da bilinçsiz mimari kurguların içinde sanatına yön vermekte, yolunu çizmekte ve ürününü ortaya koymaktadır (Allmer, 2010, s. 31). 


\subsubsection{Başlangıç Filmi:}

\begin{tabular}{|l|l|}
\hline \multicolumn{2}{|l|}{ Başlangıç / Inception } \\
\hline Yönetmen: & Christopher Nolan \\
\hline Senaryo: & Christopher Nolan \\
\hline Oyuncular: & $\begin{array}{l}\text { Leonardo Di Caprio, Marion Cotillard, Joseph Gordon-Levitt, Ellen } \\
\text { Page, Michael Caine }\end{array}$ \\
\hline Türü: & Bilimkurgu, Aksiyon \\
\hline Yapımcı: & Christopher Nolan, Emma Thomas \\
\hline Yapım yılı ve yeri: & 2010, İngiltere, ABD \\
\hline
\end{tabular}

Başlangıç filminde mimarlık eğitimi almış olan karakterin yaşadığı olaylar dizisini görmekteyiz. Filmde rüya içinde rüya fikri işlenmektedir. Rüyaları kullanarak rüya sahibinden bilgi sızdırmayı hedeflemektedirler. Öncelikle rüya içerisinde mekanlar ve kurgular oluşturmaktadırlar. Hayal gücünü ve aldıkları eğitimleri birleştirerek rüya içerisinde dikkat çekmeden rüya sahibine her şey normalmiş düşüncesi vererek bu fikir hırsızlığını gerçekleştirmektedirler. Rüya sahibi bu tarz bilinçaltı işlemlerine karşı eğitim almış olabilmektedir, bunun için de rüya içerisinde paradokslardan yararlanmaktadırlar. Paradokslar birçok filmde karşımıza çıkmaktadır. Resimlerde bile algılanması güç olan bu paradokslar filmlerde kolayca işlenebilmektedir. Paradokslardan yararlanmalarındaki hedef rüya sahibinin rüyasındaki figürlerin saldırılarından kurtulmaktır. Fotoğraf 6 'da filmdeki paradoks sahnesi görülmektedir. Filmde hayal gücünün rüya ile birleşimini ve farklı mekanların yaratılmasının mümkün olmasını görülmektedir. Rüya içinde rüya yapmaları farklı kurgu ve farklı mekanlar tasarlamalarını gerektirmektedir. Bu yüzden filmde bu amaçları en iyi gerçekleştirebilecek mesleğin mimarlık olduğunun da vurgulandığını bu işlemi yapacak kişinin mimar olmasından dolayı vurgulandığını görmekteyiz.

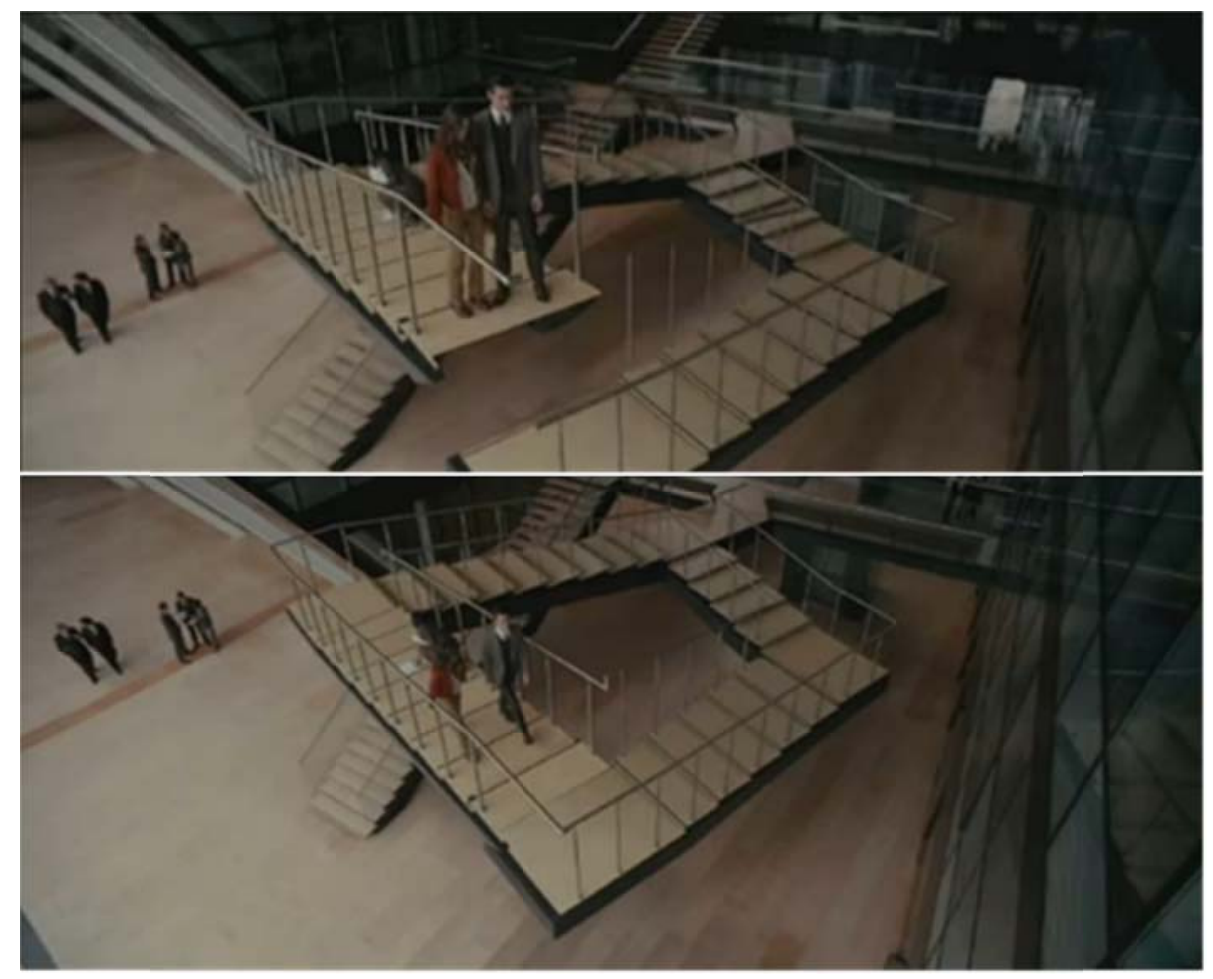

Fotoğraf 5: Paradoks Sahnesi (Başlangıç) 


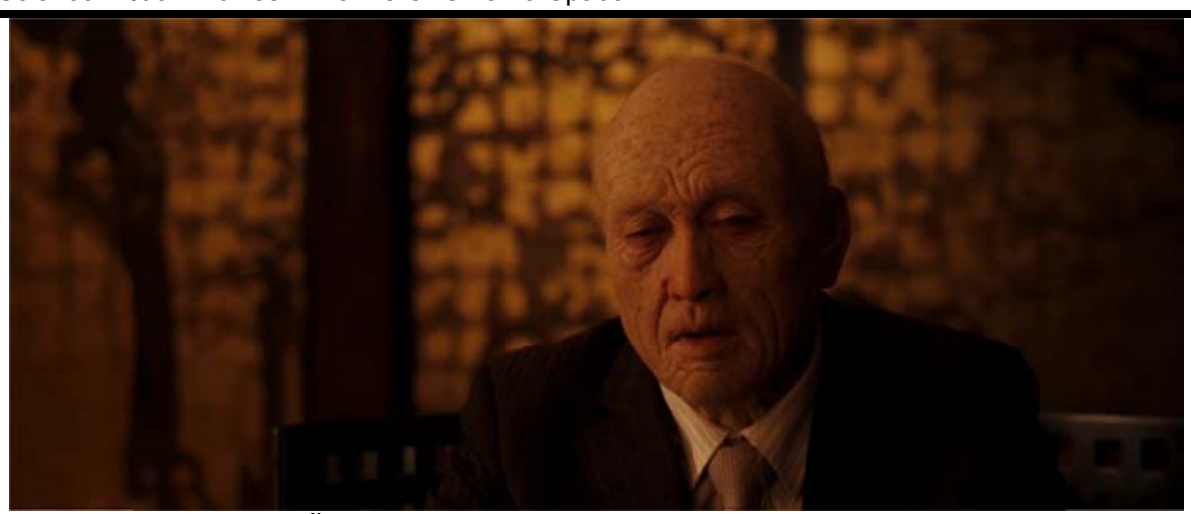

Fotoğraf 7 Üçüncü Aşama Rüyada Karakterin Yaşlanmış Hali

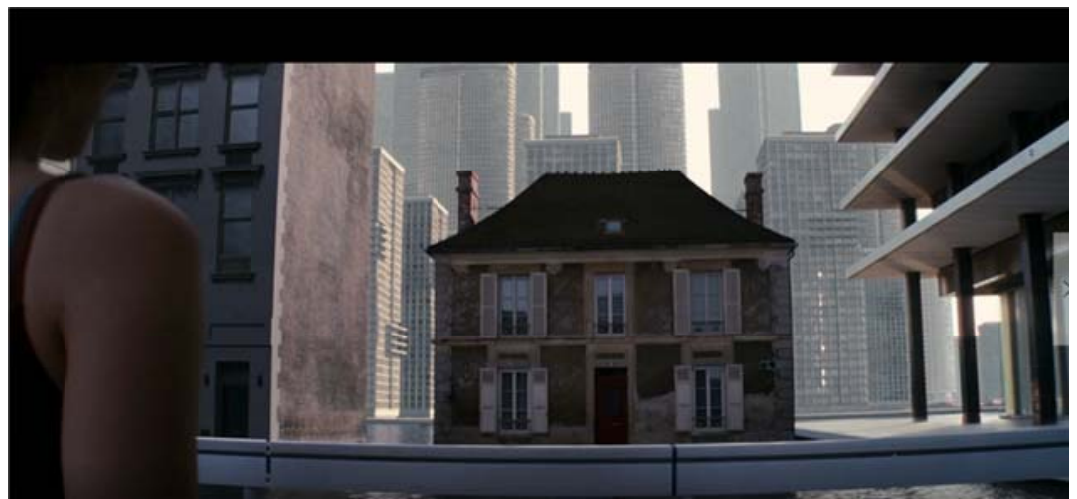

Fotoğraf 6 Ana Karakterlerin Tasarlamış Oldukları Şehir

Filmde zaman kavramı da irdelenmiştir. Rüyada geçen zaman gerçek zamandan çok farklıdır. Filmde rüyanın üçüncü aşamasında ana karakterlerden birinin rüyada çok fazla kaldığından dolayı yaşlandığı ve karakterin gerçekle sanalı artık ayırt edemez duruma geldiği görülmektedir (Fot.7). Yaşamış olduğu boyutu gerçek olarak kabul etmektedir. Karakterlerden bir diğeri bu gerçeklik algısını ona hatırlatmaya, unutmuş olduğu rüya gerçeğine onu inandırmaya çalışmaktadır.

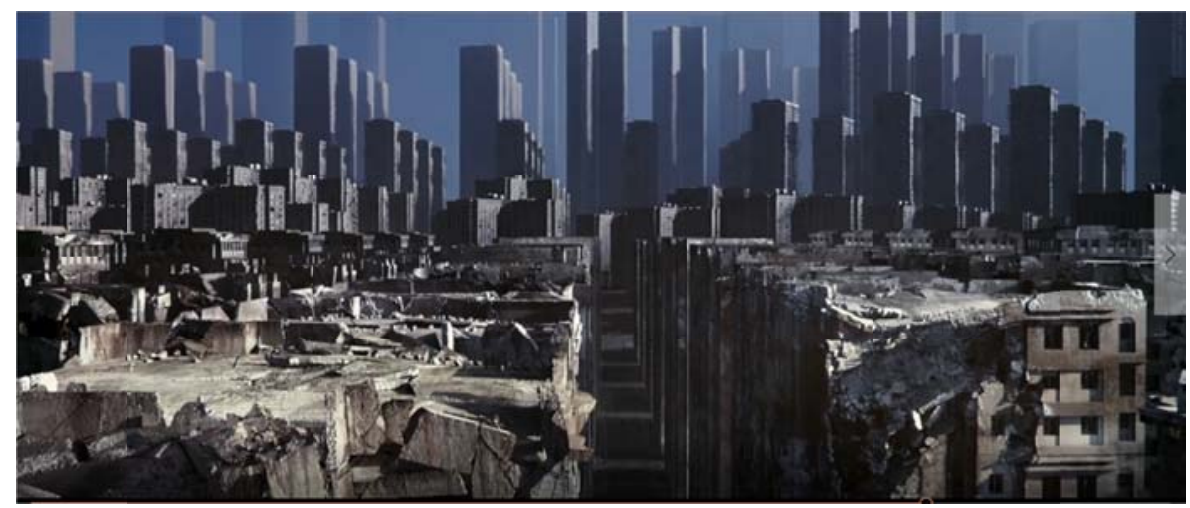

Fotoğraf 7: Ana Karakterlerin Tasarlamış Olduğu Şehrin Son Hali 


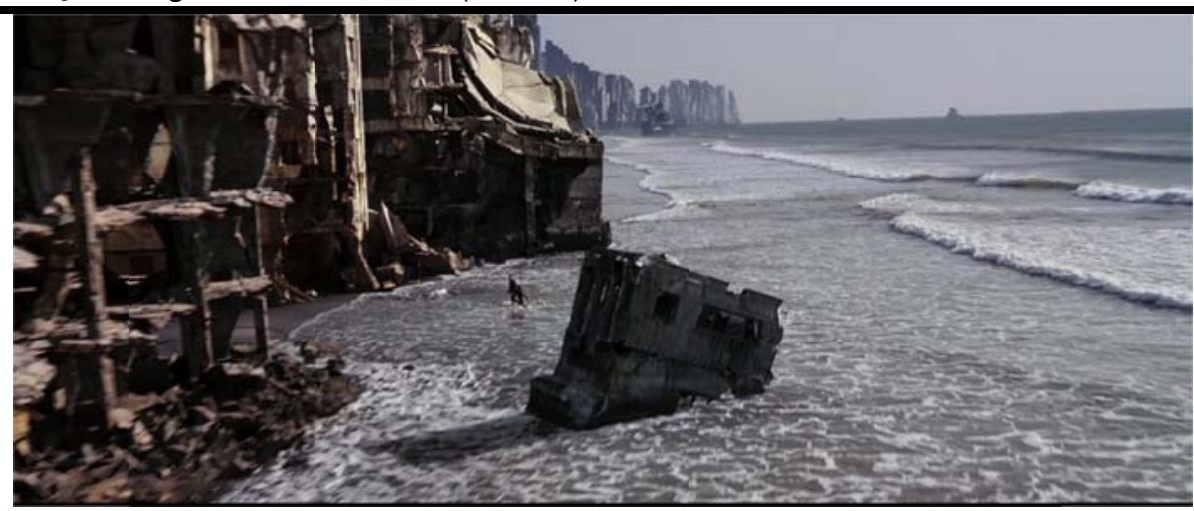

Fotoğraf 10: Ana Karakterlerin Tasarlamış Olduğu Şehrin Son Hali

Filmin sonlarına doğru filmin ana karakterinin eşi ile birlikte tasarlamış; oldukları şehrin görüntüsüne yer verilmektedir (Fot. 8). Binaları anılarından ve hayal güçlerinden faydalanarak tasarlamışlardır. Rüya içerisinde geçirdikleri zaman bütün bir şehri tasarlamalarına yeterli olmuştur. Rüyadaki mekânı terk ettikten yıllar sonra geri dönüldüğünde şehrin harabeye dönüştüğü gözlemlenmektedir (Fot. 9-10). Şehirdeki yok oluş kurgusal bir şekilde verilmiştir. Şehirde ana karakterin ailesi dışında kimsenin olmaması göze çarpmaktadır. Sürekli depremler ve yıkım olmaktadır. İnsanlar olmadığı zaman veya kullanılmayan binaların yok oluşuna bir gönderme yapıldığı düşünülmektedir. Rüya içerisinde hayal güçlerini kullanarak farklı özelliklere sahip binalar tasarlayabilmişlerdir. Daha yüksek binaların rüya içerisinde yapıldığını, gerçek dünyanın sınırlayıcılığından uzak tasarımların rüya içerisinde nasıl işlendiği filmde görülmektedir. Tasarlamış oldukları binalar gerçeğe çok yakındır. Filmdeki bu sahnede yeşile yer verilmediği doğadan uzak bir şehir tasarlamış oldukları gözlemlenmektedir.

\subsubsection{Azınlık Raporu filmi:}

\begin{tabular}{|l|l|}
\hline \multicolumn{2}{|l|}{ Azınlık Raporu / Minority Report } \\
\hline Yönetmen: & Steven Spielberg \\
\hline Senaryo: & Scott Frank, Jon Cohen \\
\hline Oyuncular: & $\begin{array}{l}\text { Tom Cruise, Colin Farrell, Paul Wesley, Peter Stormare, Kathryn } \\
\text { Morris }\end{array}$ \\
\hline Türü: & Bilimkurgu, Aksiyon, Gizem \\
\hline Yapımcı: & Jan de Bont, Gary Goldman \\
\hline Yapım yılı ve yeri: & 2002, ABD \\
\hline
\end{tabular}

Film 2054 yılındaki bir dünyayı ele almaktadır. Teknolojik gelişmeler düşünülerek kurgulanmış bir filmdir. Filmde üç kâhinin ön gördükleri cinayetlerin teknolojiden de yararlanılarak cinayetler gerçekleşmeden tespiti ön plana çıkmaktadır. Cinayet çözümlemeleri suç öncesi adı verilen bir birim tarafından gerçekleştirilmektedir. Filmdeki ana karakter bu birimde çalışan kişilerden biridir. Filmde yer alan bazı teknolojiler günümüzde de kullanılmaktadır. Filmdeki mekanlarda cam, metal, beton görünümlü malzemeler çoğunlukla tercih edilmiştir. 
Fotoğraf 9 Suç Öncesi Biriminden Bir Görünüm

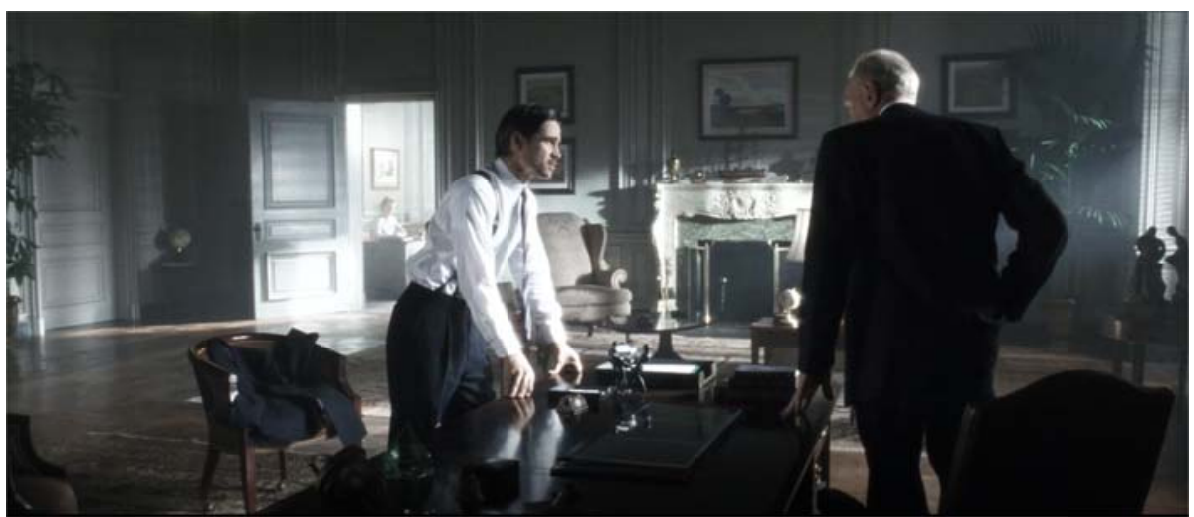

Fotoğraf 10 Filmde Geçen Konut İç Mekanlarından Bir Görünüm

Filmde kentten uzak konut mekanlarının günümüzde tasarlanan villa tasarımlarıyla aynı oldukları görülmektedir. Yardım'a göre bunun nedeni; seyircinin tamamen zaman ve mekândan kopmaması adına geçmiş yaşantısından edindiği görsel birikimlerle karşılaşması gerekliliğidir (Yardım,2012, s. 142).

Şehir merkezi ise ileri teknolojik bir şehir olarak karşımıza çıkmaktadır. Şehir sokaklarında, alışveriş mekânlarında, mağazalarda; kişiyi tanıyan ve ona özel reklam avantajı sunan sistemler mevcuttur.

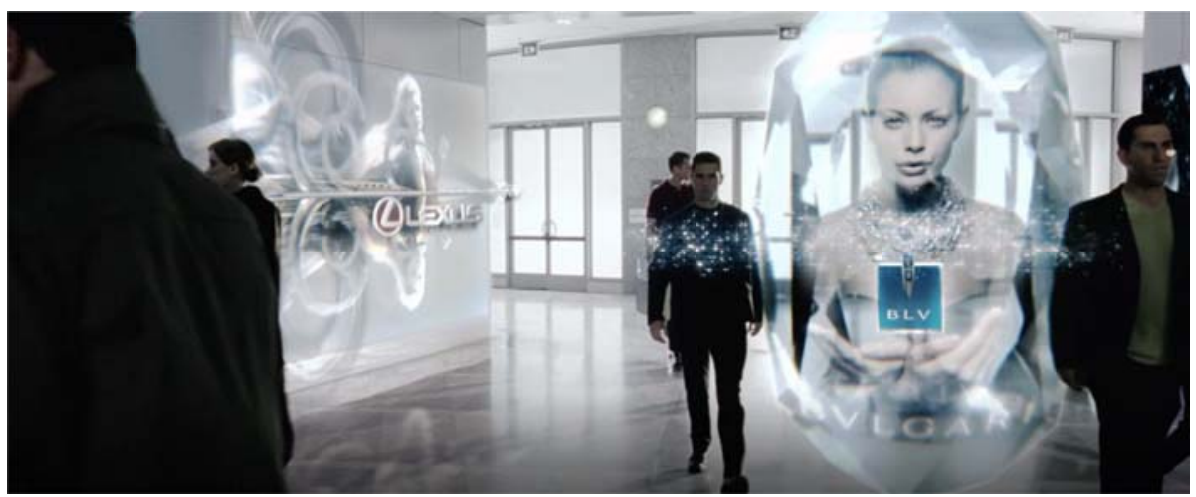

Fotoğraf 11 Filmde Geçen Şehir Merkezinden Bir Görünüm 


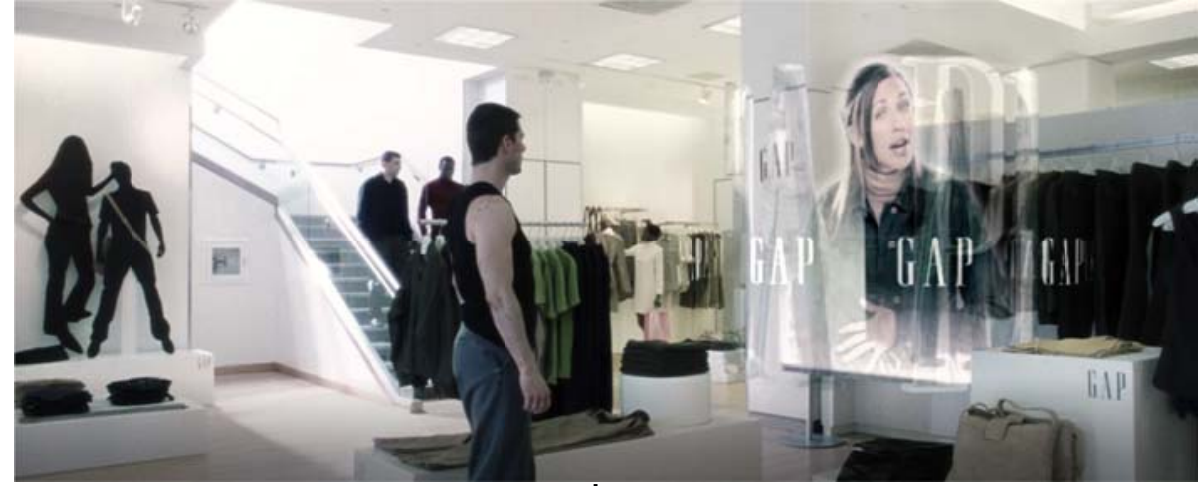

Fotoğraf 12 Filmde Geçen İç Mekanlardan Bir Görünüm

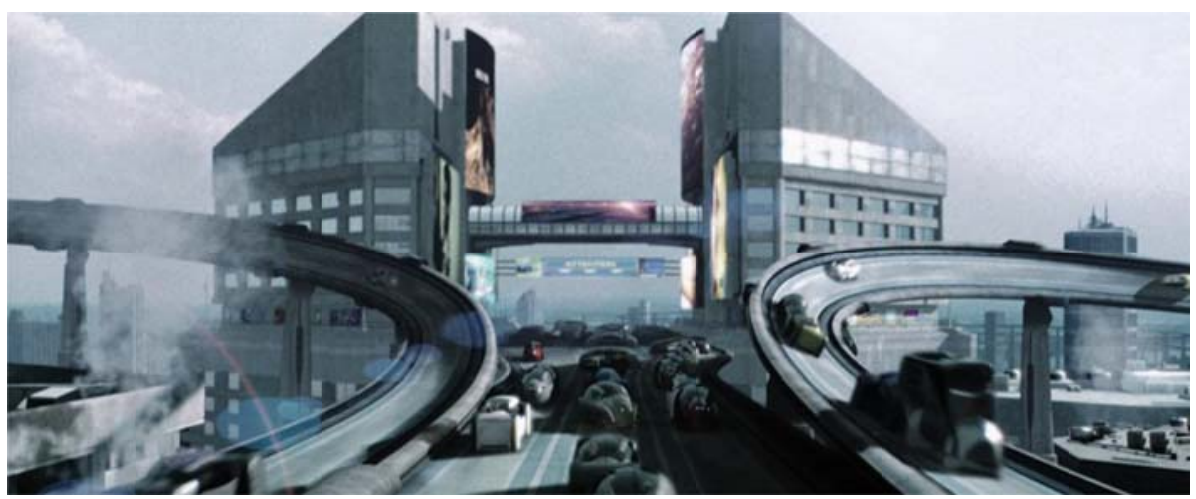

Fotoğraf 13 Filmde Geçen Mağazadan Bir Görünüm

Bilim kurgu filmlerinin çoğunda olduğu gibi bu filmde de fütürizm akımının etkisini görülmektedir. Bu akımda benimsenen yenilik arayışları, bilimsel ilerlemeler de düşünülerek kurgulanır. Gelişen teknolojik gelişmeleri günlük yaşama irdelemek, sosyolojik ve toplumsal alanlarda oluşabilecek düzeni sorgulamak bu akımın başlıca amaçları arasında sayılabilir.

Sinema, kurgusal gerçekliğe yer verirken; fütürizm ise filmde kullanılan teknolojiyi "olağanüstü" algısından kurtarmaya çalışır. Temel olarak gelecekçilik olgusu, filmde işlenen gerçeklik ile özdeşleşmektedir. Bu şekilde seyircinin, gerçek dünya da henüz görmediği yeniliğin hayalini kurması, yönelmesi ve ihtiyaç duymaya başlaması amaçlanmaktadır (Boyar,2016, s. 163).

2010 yılında yayınlanmış bu film, dönemi açısından insanları ileri teknolojiye alıştırır niteliktedir. Konut iç mekanlarında işlenen teknolojik gelişmelerin birçoğunun günümüz teknolojisinde yerini aldığı gözlenmektedir. Şehir merkezinde gelişen ulaşım teknolojisi binaların tasarımını etkilemiştir (Fot. 14). Filmde işlenen ulaşım teknolojisi ve mekanları günümüzde bulunmamaktadır. Filimde gösterilen mağaza iç mekanlarındaki veya alışveriş merkezi iç mekanlarındaki teknolojik gelişmeler günümüz mekanlarında bulunmamaktadır (Fot.15,16).

\subsection{Sinema Mekânı Temsil Eder:}

Sinema, mekânların tasarlanması ya da düzenlenmesi için adeta bir laboratuvar niteliğindedir. Yönetmen bu noktada belki de bir mimardan daha özgürdür, çünkü yarattığı şey tamamen düşsel bir gerçekliktir; bu da ona büyük bir serbestlik kazandırır. Fakat mekânın nasıl kullanıldığı oldukça önemlidir. Çünkü bir mekân sadece bir anlığına da olsa, hiçbir açıklamaya gerek duymaksızın, seyircinin görsel algısına 
doğrudan hitap ederek anlatılmak isteneni yansıtabilir Hemen hemen tüm sinema türlerinde bir mekân anlayışı mevcuttur. Belki bir oda, belki bir şehir, belki de küçük bir kasaba filmin içindedir ve tüm gerçekliğiyle karşımızdadır. Anlatılmak istenen hikâye ile ilgili- toplumsal, fiziksel yapı gibi- bilgiler, hiçbir alt metin olmadan mekanlar aracılığı ile gerçek dünyaya göndermeler yaparak sunulur, ya da tamamen hayali bir tasviri seyircinin algısına yepyeni imajlar sunabilmektedir. Örneğin bilimkurgu filmlerinde öne çıkan gelecek tasviridir. Bu bağlamda yönetmen fütüristtik bir yaklaşımla mekânı tasarlamakta: Binalar makineleşir, renkler ve simgeler donuklaşır, özetle mekânın tasarlanışında teknoloji ön plana çıkmaktadır. Bu yöntem tüm sinema türleri için geçerlidir; mimari unsurlar sinemada büyük bir rol oynamakta ve detaya inilecek olursa, bir kolon bile senaryoya göre şekillenebilmektedir (Allmer, 2010, s. 59).

\subsubsection{Açlık Oyunları filmi:}

\begin{tabular}{|l|l|}
\hline \multicolumn{2}{|l|}{ Açlık Oyunları 1 / The Hunger Games 1 } \\
\hline Yönetmen: & Gary Ross \\
\hline Senaryo: & Billy Ray Cyrus, Suzanne Collins \\
\hline Oyuncular: & $\begin{array}{l}\text { Jennifer Lawrence, Josh Hutcherson, Elizabeth Banks, Woody } \\
\text { Harrelson, Liam Hemsworth }\end{array}$ \\
\hline Türü: & Bilimkurgu, macera, aksiyon \\
\hline Yapımcı: & Suzanne Collins, Nina Jacobson \\
\hline Yapım yılı ve yeri: & 2012, ABD \\
\hline & Tablo 3 Açlık Oyunları filmi hakkında bilgiler \\
\hline
\end{tabular}

Film distopik bir gelecekte yaşanılanları anlatmaktadır. Üç filmden oluşan seri bir filmdir. Filmin başında film hakkında kısaca bilgi verilmektedir:

Ihanet antlaşmasından: her mıntıka ayaklanmalara karşı bir ceza olarak haraç olarak adlandırılan 12 ila 18 yaş arasındaki evlatlarını vermek zorundadır. Bu haraçlar Capitol'ün himayesine teslim edilmelidir. Daha sonra bu haraçlar bir açık hava arenasına götürülerek, en sonunda tek bir kazanan kalana dek sürecek ölümüne bir mücadele vermeye başlayacaklardır. Bundan böyle bu törensel oyunun adı sonsuza kadar Aıçlık Oyunları olarak anılacaktır. Bu bizim bir geleneğimiz. Tarihimizin acı dolu zamanlarını yansıtıyor. Ama aynı zamanda düzelmemizi sağlayan bir yol. İlk başlarda ayaklanmaları hatırlatan bir şeydi; mıntıkaların ödemesi gereken bir bedeldi. Âmâ artık bundan daha da fazlası. Bu bizi birbirimize bağlayan bir şey...

Filmin başında bir sunucu ve bir konuğun bulunduğu bir sahneyle karşılaşmaktayız. Giyimlerinin ve bulundukları mekânların günümüz tarzlarından farklı olduğu görülmektedir.

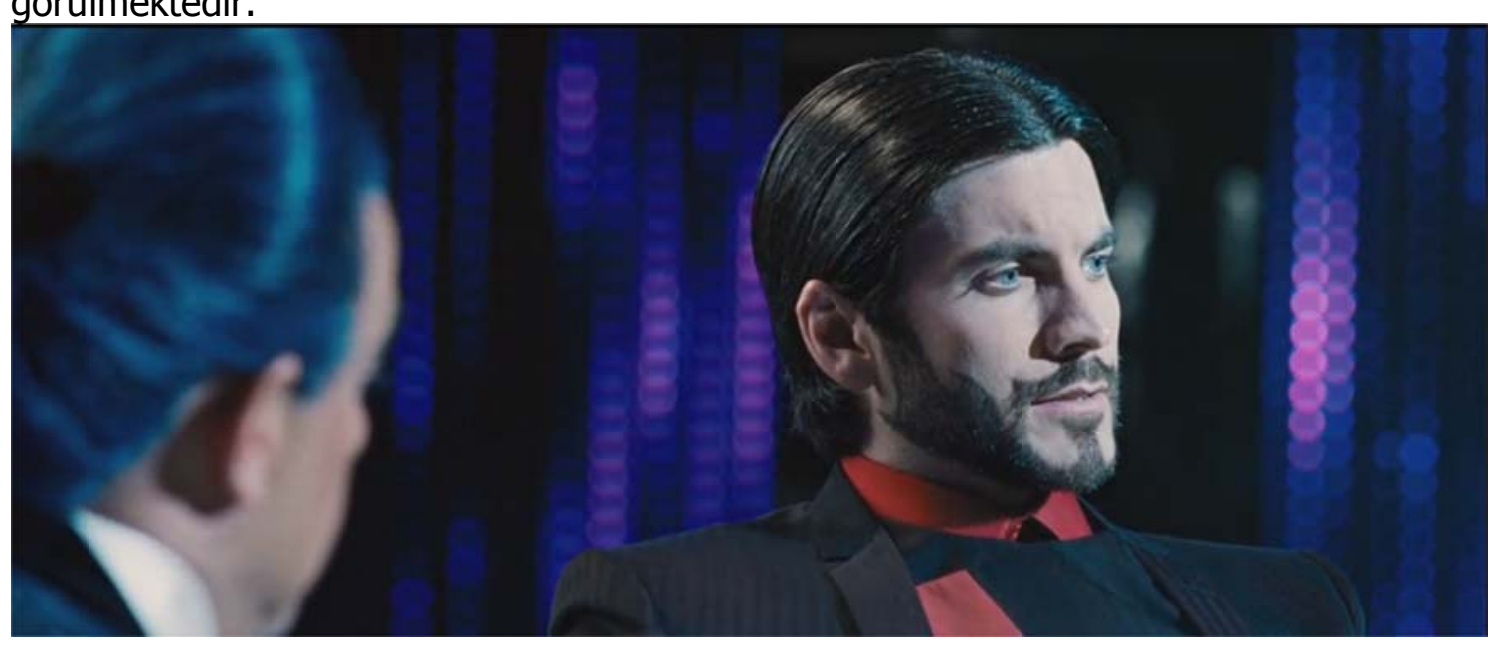

Fotoğraf 14 Filmin Başlangıcından Bir Sahne 
Daha sonra, alt gelir seviyesine hitap eden evlerin bulunduğu bir köy karşımıza çıkmaktadır. Her mıntıkadan haraç olarak bir erkek ve bir kadın birey seçilmektedir. Haraçları seçmek için barış muhafızları mıntıkalara gelmektedir. Açlık oyunları ülkenin her yerinde zorunlu olarak canlı yayınlanmaktadır. Çekiliş yapılacak meydanın her yeri dezenfekte edilmektedir, bu da başkent ve mıntıkalar arasındaki farklılı̆ı algılamamızı sağlamaktadır.

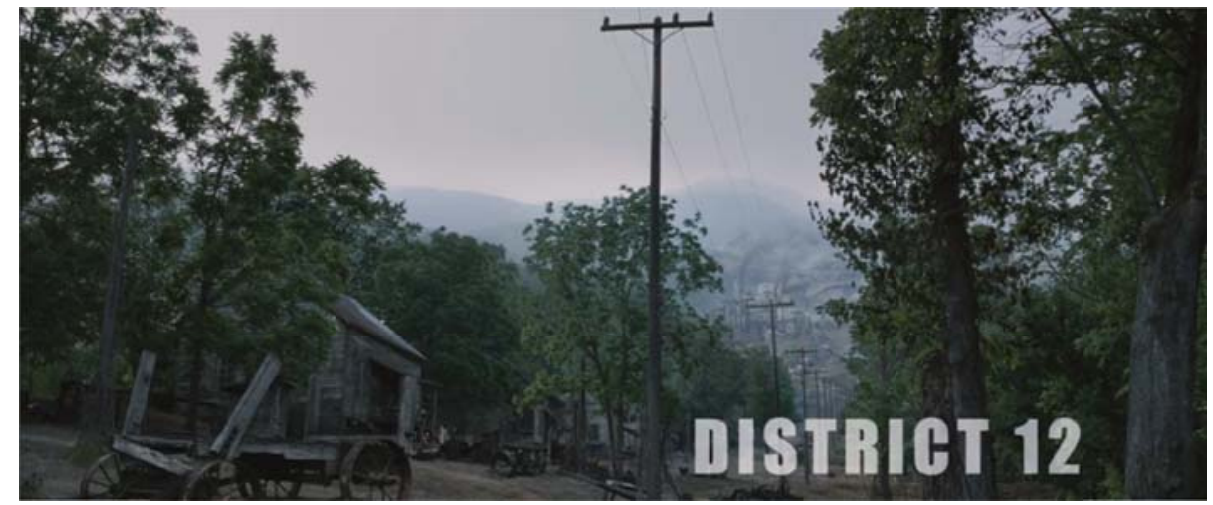

Fotoğraf 15 Mıntıka 12'den bir görünüm

Sinemanın kenti perdeye aktarması, başka bir değişle yeniden üretmesi sinema ve mimarlık ilişkilerinin diğer bir konusunu oluşturur. Öncelikle film; fotoğraf gibi gerçekliğin bir kanıtıdır. Bilimsel veri olarak kullanılabilmektedir. Aynı zamanda kenti ve mekânı her zamanki sıradan görüntüsünden kurtarıp daha etkili bir şekilde gösterebilme yetisine sahiptir. Bu sebeple, filmin ilk önemsenen yönü, kenti ve mekânı temsiliyeti, insanların bunu algılaması üzerinedir (Babaoğlu,2004, s. 25).

Seçilen haraçlar başkente doğru yola çıkmaktadır. Filimde başkent ile mıntıka mekanları temsil ettikleri kesimi yansıtmaktadır. Filmde başkent ile mıntıkalar arasındaki mekanlar arası eleştiriler başkentin gelişmişliğine ait bir mekân gösterilirken; karakterin aklına gelen kendi yaşamış olduğu bir olay gösterilerek anlatılmaya çalışılmıştır. Haraçların gelmiş oldukları tren istasyonunun günümüz tren istasyonlarından farklı olduğu gözlenmektedir. Tren istasyonundaki insanların giyim tarzları ve saç stilleri günümüzdekinden oldukça farklı olduğu görülmektedir.
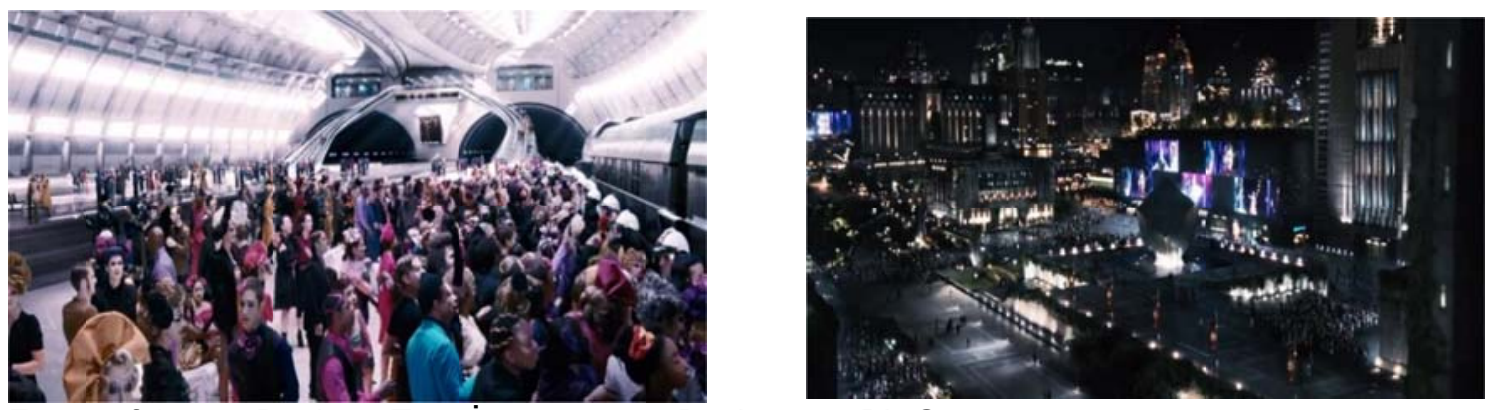

Fotoğraf 16-20 Başkent Tren İstasyonu ve Başkentten Bir Görünüm 


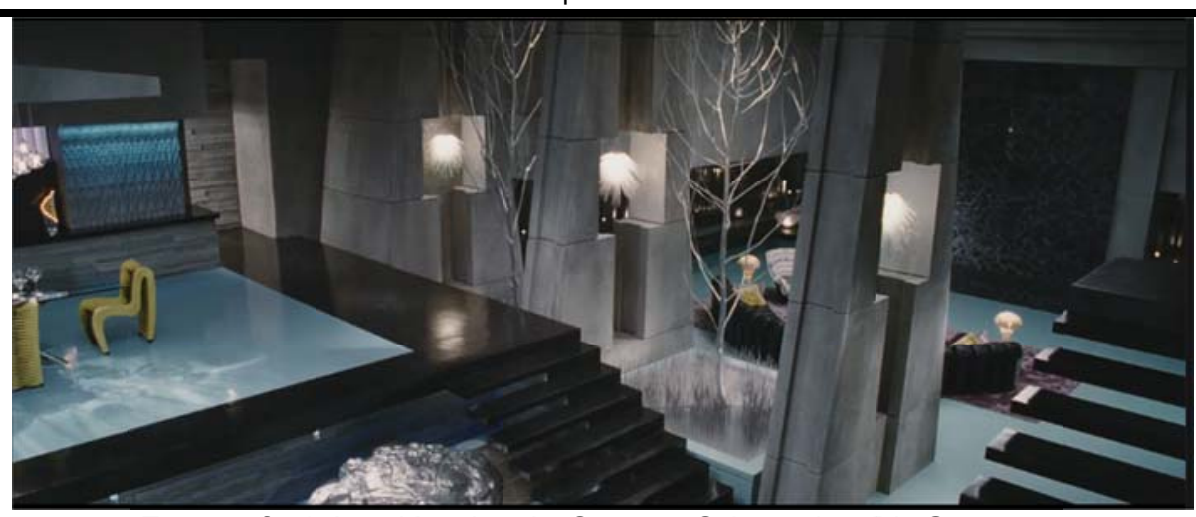

Fotoğraf 21 Ana Karakterin Oturma Odasından Bir Görünüm

Filmin ana karakterlerinden biri olan Katness'in dinlendiği odada mekansal ihtiyaçlar günümüz intiyaçlarıyla aynıdır. Mekanda teknolojiye de yer verilmiştir. Yatak odasının penceresi aynı zamanda bir TV olma özelliği göstermektedir. (Fot. 21)

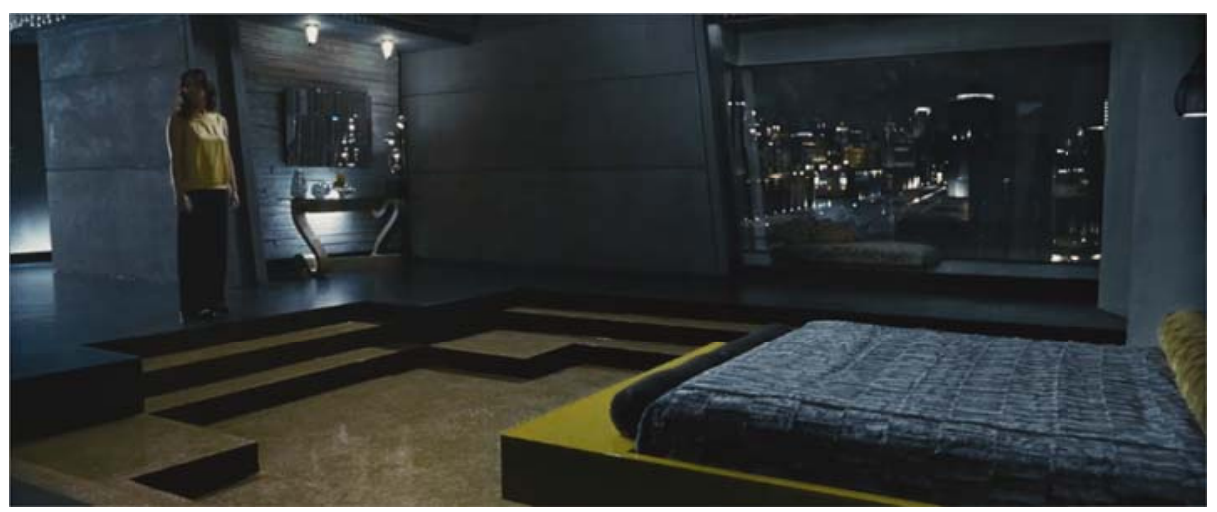

Fotoğraf 22 Ana Karakter 'in Yatak Odası

Başkentte bulunan mekanların, başkentte yaşayan yüksek gelir sahibi insanların yaşam tarzlarına göre tasarlanmış olduğunu görmekteyiz. Haraçların kaldıkları yatak odaları mıntıkadakilerden oldukça farklıdır. Bunun sebebi de mekanın bulunduğu yerin kendisinden daha üst seviyedeki insanlara hitap eden bir yer olmasından kaynaklanmaktadır. Tabakalar arası farklılıklar sahip olunan hakların dışında her türlü yaşamsal ihtiyaçlarda göz önüne serilmektedir. Başkentte son teknoloji ürünlere, en pahalı tasarımlara yer verilirken mıntıkalarda durum bunun tam zıttıdır. Bu zenginlik ve tabakalar arası farklılık filmde gösterilirken ışığın etkisinden, yüksek binalardan ve teknolojiden yararlanılmıştır. Tekstil ürünlerinde bile bu farklılığı görmekteyiz. Açlık Oyunları filmi mekânı temsil eder başığında incelenmesine rağmen aynı zamanda senaryo gereği dünyanın gelebileceği düzeni eleştirir niteliktedir. Zenginler ile fakirlerin arasının açılması sonucu oluşan sınıf farklılığı filmde iyi bir şekilde incelenmiştir. Bu sınıfların mekanları temsil edilirken aynı zamanda sınıflar arasındaki farklar eleştirilmiştir.

\section{SINEMA MEKÂN TASARIMINI ETKILER:}

Bilimkurgu filmleri incelendiğinde mekân tasarımına iki etkisi olduğu görülmektedir. Birincisi sinemada kurgulanan mekanlara, ikincisi günlük yaşamda kullandığımız mekanlara etkisinin olduğudur. Bilimkurgu filmleri; konuları, senaryoları, oyuncuları kadar tasarımlarıyla da dikkat çekmektedir. Tasarlanan bu filmlerde kullanılan ürünler grafik tasarımlar, ayakkabılar, kıyafetler izleyicilerin dikkatini çekmekte ve tasarımcıların bu filmleri konsept alarak çeşitli tasarımlar yaptıkları görülmektedir. İncelenen filmlerden Tron Efsanesi birçok tasarımcının dikkatini çekmiş ve filmde 
kullanılan unsurları kullanarak çeşitli tasarımlar yapmışlardır. Bu tasarımlar tekstil, ayakkabı, grafik tasarım sektörlerinde olduğu kadar iç mekân tasarımlarında da karşımıza çıkmaktadır. Örneğin; mobilya, mutfak, banyo, yatak odası tasarımları bu filmden esinlenerek yapılmış ve büyük tercih görmüştür.
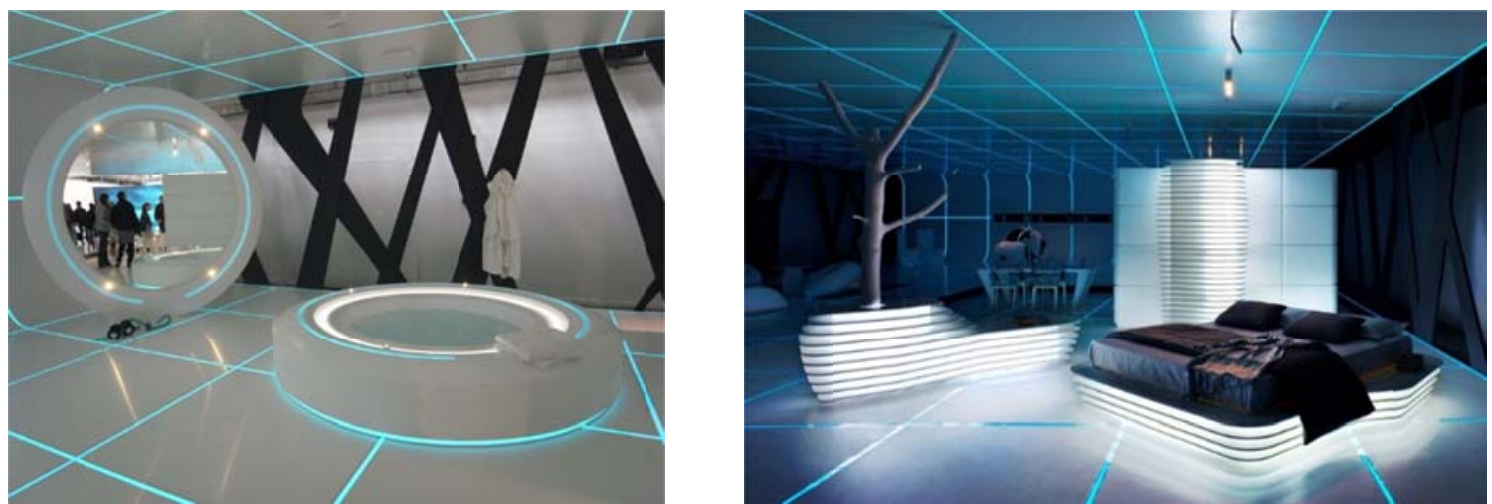

Fotoğraf 17 Tron Efsanesi filmi konseptiyle tasarlanan mobilya ve mutfak örneği [URL1-2]
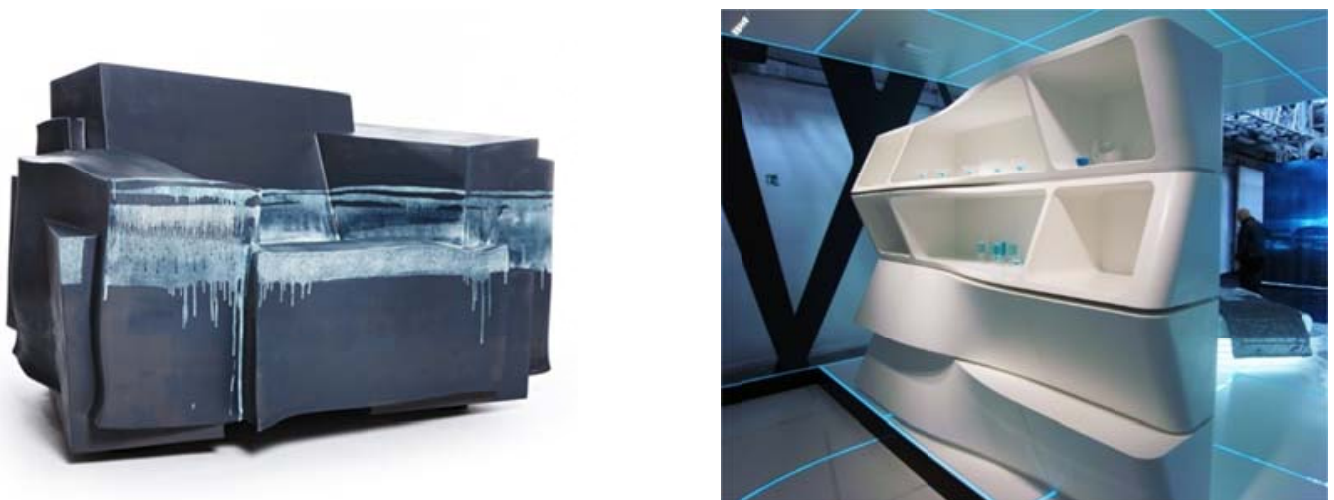

Fotoğraf 18 Tron Efsanesi Filmi Konsepti ile Tasarlanan Banyo ve Yatak Odası Örneği [URL-2]

İncelenen Azınlık Raporu filmi ise gelecekte kullanılacağı öngörülen malzemeler açısından tasarımcıların dikkatini çekmiştir. Bu filmde kullanılan birçok mekân ögesi ve teknolojik öge günümüzde kullanılmaktadır. Filmdeki yaşam kurgusu diğer film yapımcılarının da dikkatini çekmiş ve 2015 yılında filmin televizyon serisi yapılmıştır. Bu televizyon serisinde ise Azınlık Raporu filminden altı yıl sonrası ele alınmaktadır.
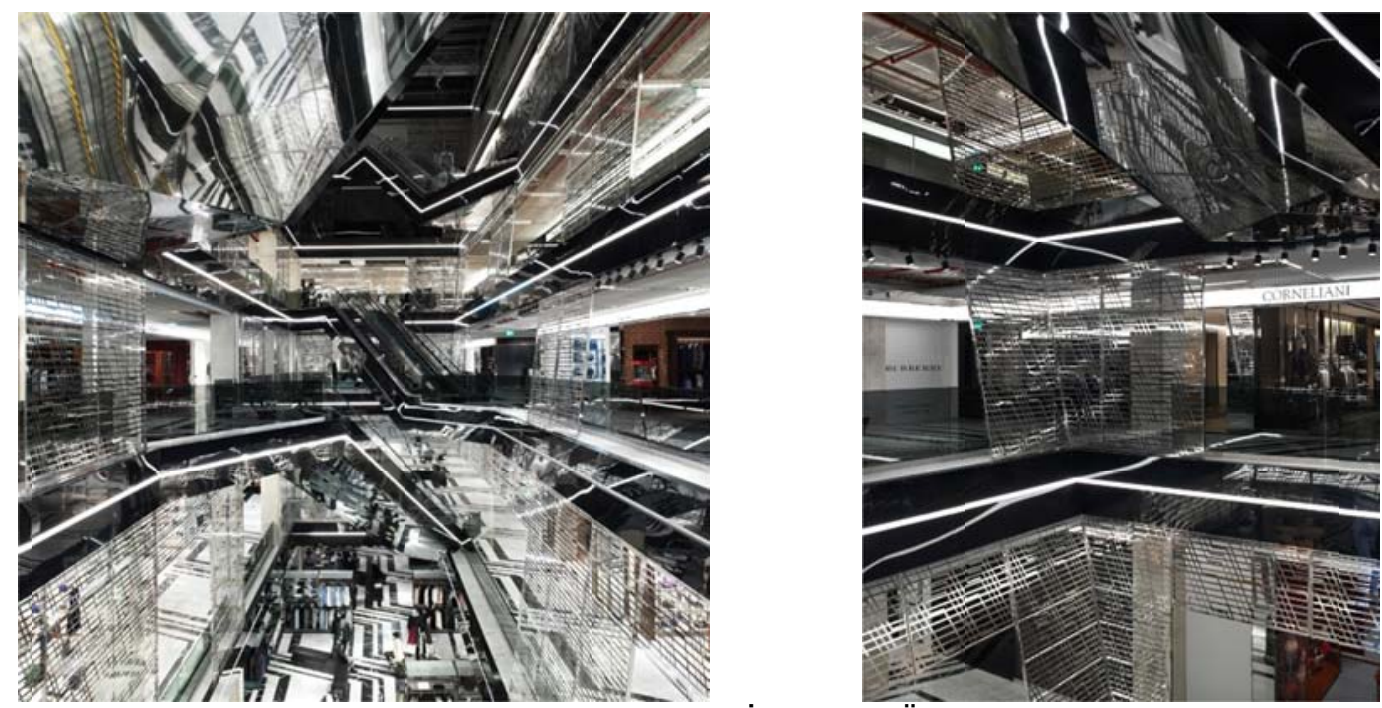

Fotoğraf 19 Fütüristtik Yaklaşımla Tasarlanan Yapı İç Mekân Örneği [URL-3] 

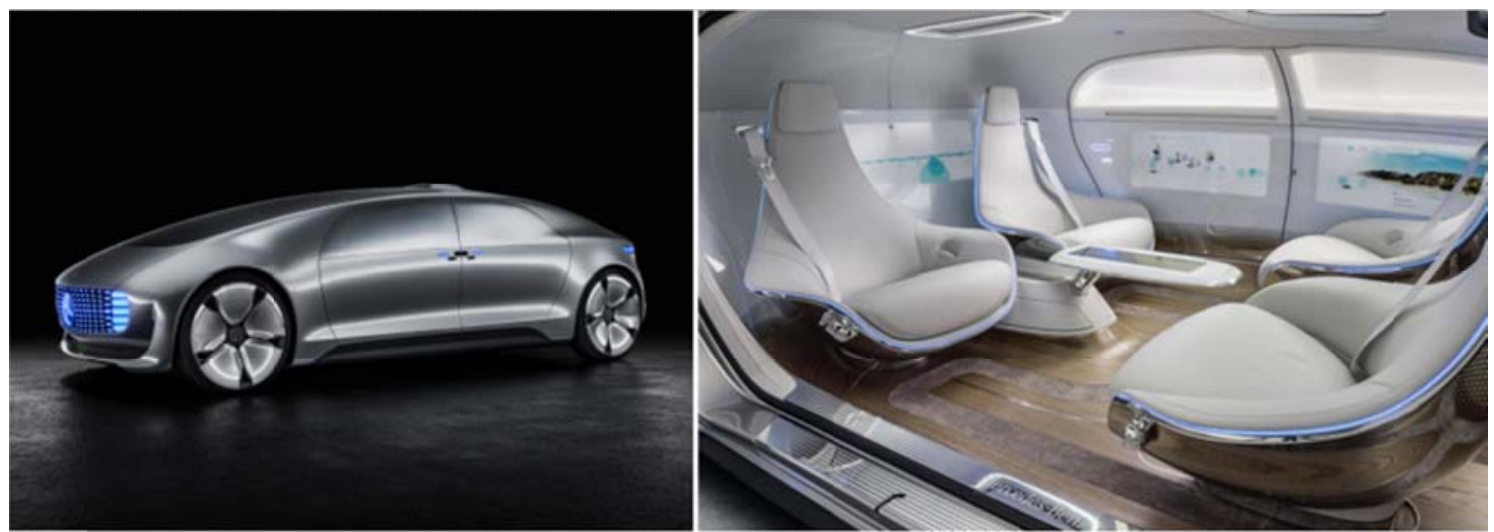

Fotoğraf 20 Azınlık Raporu Filminden Esinlenerek Tasarlanan Otomobil Örneği [URL-4]

\section{DEĞERLENDIRME VE SONUÇ:}

Çağdaş bilim verileriyle düş gücünden oluşan film olarak tanımlanan bilimkurgu filmlerinin; farklı problemleri, düşünceleri, ütopya ve distopyaları ele alarak şekillendiği görülmektedir. Bu filmler kurgulanırken olayların geçtikleri mekanlar da filmin konusuyla birlikte filmdeki karakterlerin intiyaçları, filmin geçtiği dönem düşünülerek şekillenmektedir. Bilimkurgu filmleri sadece geleceği kurgulamamakta, farklı zaman ve boyutlarda geçen filmleri de kapsamaktadır. Bu çalışmada dört farklı film belirtilen başlıklar altında incelenerek ele alınmıştır.

Bu başlıklar şunlardır:

1. Sinema mekânı eleştirir,

2. Sinema mekânı düşletir,

3. Sinema mekânı temsil eder,

4. Sinema mekân tasarımını etkiler.

$\mathrm{Bu}$ çalışmada incelenen başlangıç, Tron Efsanesi filmi var olmayan mekanlarda kurgulanmış filmlerdendir. Başlangıç filmi rüya içinde rüya olgusuna dayanarak oluşturulmuş bir filmdir. Tron Efsanesi filmi ise bir oyun konsolunun içinde var olmayan bir boyutta geçen bir filmdir. Azınlık Raporu 2052 yılında dünyanın nasıl olabileceği düşünülerek bilinen mekanlarda geçen bir filimdir. Açlık Oyunları ise yıakın bir gelecek düşünülerek var olmayan bir sistemde ve var olmayan bir ülkede geçmektedir. Mimarlık anlayışının sinema filmini geliştirdiği gözlemlenmiştir. Mekânı oluşturan unsurların filme göre şekillendiği görülmüştür. Geleceği yansıtan mekanlarda metal, cam gibi yansıtıcı materyallerin ve renk olarak beyaz ve grinin tercih edildiği görülmektedir. Doğal malzemeler fazla görülmemektedir. Bunun nedeninin teknolojinin gelişmesiyle birlikte farklı materyallerin doğal malzemelerin yerini alabileceği intimali olduğu düşünülmektedir. İncelenen bu filmlerin günlük hayatta kullandığımız tasarımlara da etkisi olduğu görülmüştür. Farklı unsurları ele almaları filmlerin dikkat çekiciliğini arttırmıştır. Açlık Oyunları'nda kullanılan tekstil ürünleri günümüzde kullanılmamaktadır. Bununla birlikte filmde tasarlanan birçok tasarım günümüzdeki tasarımcıların dikkatini çekmiştir. Bilimkurgu filmlerinde mekân tasarımının iki etkisi olduğu öngörülmüştür. Birinci etkisinin filmlerdeki mekanlar olduğu düşünülerek filmdeki mekanlar başlıklar altında incelendikten sonra, diğer etkisi, bu filmlerin günlük yaşama etkileri farklı bir başlık altında incelenmiştir. Bilimkurgu filmlerinin tasarıma yenilikler getirdiği öngörülmüştür. Bu filmlerde kullanılan farklı malzemeler tasarımcıların dikkatini çekmiş ve tasarımlarında o malzemelere yer vermişlerdir. Tron Efsanesi'nde kullanılan iç mekân ögelerinin günümüzde de üretilmeye çalışıldığı ve filmdeki etkiyi verebileceği 
düşünülen corian malzemesi kullanılarak bu tasarımların gerçek hayata geçirildiği görülmüştür.

Sonuç olarak görülmektedir ki; sinema insan yaşamını her türlü boyutuyla ele alan organik bir görsel anlatımdır, mimarlık disiplini ile en iç içe olan sinema türü bilimkurgudur. Var oluşun çeşitli temsillerini üreten bir sanat dalı olan sinemanın bilimkurgu sineması-mekân tasarımı ile ilişkisi kaçınılmazdır. Bilimkurgu filmlerinin mekân tasarımı alanıyla kesişim gösterdiği en önemli konulardan biri var olmayan mekanları kurgulamasıdır. Yenilikçi filmler geleceği görme, yaşama ve var oluş tarzları ile insanların geleceği tasavvur etmelerine yardımcı olmaktadırlar. Sinema, mekanların tasarlanması ve düzenlenmesi için bir laboratuvar niteliğindedir. Bilim kurgu filmleri, mekân tasarımına etki ettiği gibi mekânın tasarımı da filmleri etkilemektedir. Günümüzde mekân kullanımını etkileyen "moda"," kültür" gibi kavramlarında sinema yoluyla etkilendiği ve tasarımların yönlendiği açıkça görülmektedir.

\section{KAYNAKÇA:}

Aristoteles, Fizik, Yapı Kredi Yayınları, 2.Basım,2001.

Allmer, Açalya, Sinemekân Sinemada Mimarlık, Varlık Yayınları,1.Basım,2010.

Ayyıldız, Sonay, Müştak, Senem, "Sinema-Mimarlık Arakesitinde Cyberpunk (Siberpunk) ve "Ada" Filmi Üzerinden Eleştirel Bir Yaklaşım", Mimarlık ve Yaşam Dergisi, Cilt: 1, No: 1, 2016.

Abisel, Nilgün, Popüler sinema ve Türler, Alan Yayıncılık, 1. Basım, 1995.

Babaoğlu, Fatih, Bilim-Kurgu Sinemasının Mimari Ütopya Kavramı Bağlamında Bir Temsiliyet Aracı Olarak Kullanılması, İstanbul Teknik Üniversitesi Fen Bilimleri Enstitüsü, Yüksek Lisans Tezi, 2004.

Beşışık, Gökçe, Sinema ve Mimarlıkta Mekân Kurgusu ve Kavrayışı, Dokuz Eylül Üniversitesi Fen Bilimleri Enstitüsü, Yüksek Lisans Tezi, 2013.

Betton, Gerard, Sinema Tarihi, İletişim yayınları, 1. Basım, 1986.

Boyar, Nihan, "Sinemada Fütürist Yaklaşım: Minority Report Filminin İncelenmesi", The Turkish Online Journal of Design, Art and Communication, Sayı: 6, 2016.

Çalışkan, Özgür, "Bilim-Kurgu Film Türünde İdeoloji Örneği: Tron Efsanesi”, 4. Uluslararası İmaj/İmge Konferansı'nda "An Example of Ideology and Representation in Science Fiction Cinema: TRON and TRON: Legacy" başlığıyla sunulan sözlü bildirinin genişletilmiş hali, 2013.

Kale, Gül, Sinemada Görsel Deneyim ve Mimarlık, İstanbul Teknik Üniversitesi Fen bilimleri Enstitüsü, Yüksek Lisans Tezi, 2004.

Kellner, Douglas, Sinema Savaşları, 1. Baskı, Çev. Güral Koca, Metis yayıncılık, İstanbul, 2013.

Özbanazı, Ozan, Çağdaş Hollywood Bilim-Kurgu Sinemasında Görsel Etkiler Ille Yaratılan Sinemasal Gerçeklik, Ankara Üniversitesi Sosyal Bilimler Enstitüsü Radyo Televizyon Sinema Anabilim Dalı Yüksek Lisans Tezi, 2004. 
Özön, Nijat, Sinema Sanatına Giriş, Agora Kitaplığı, 1. Basım, 2008.

Özen, Gökberk, Bilim-Kurgu ve Etki Alanı Üzerinden Geleceğin Yapay Çevrelerinin Değerlendirilmesi, İstanbul Teknik Üniversitesi Fen bilimleri Enstitüsü, Yüksek Lisans Tezi, 2006.

Topal, Sinem, Mekânın Yeniden Üretiminde Eksiklik ve Devinim, İstanbul Teknik Üniversitesi Fen Bilimleri Enstitüsü, Yüksek Lisans Tezi, 2013.

Yardım, Sevcan, Bilim-Kurgu Filmlerinde Mekân ve Öğelerinin Biçimlenişiyle Gelecek Algısının Oluşturuıması Üzerine Bir Araştırma, Hacettepe Üniversitesi Sosyal Bilimler Enstitüsü İç Mimari ve Çevre Tasarımı Anasanat Dalı Yüksek Lisans Tezi, 2012.

[URL-1] https://www.dezeen.com/2010/12/02/tron-chair-by-dror/ Erişim Tarihi:11.05.2017

[URL-2] http://www.designboom.com/design/tron-designs-corian/ Erişim Tarihi:11.05.2017

[URL-3] https://www.dezeen.com/2015/11/05/david-adjaye-aishti-foundationgallery-shopping-centre-nears-completion-beirut-lebanon/ Erişim Tarihi:11.05.2017

[URL-4] http://www.plan.london/the-aesthetics-of-the-autonomous-driverlesscars-are-coming-but-what-style-will-triumph/ Erişim Tarihi:11.05.2017

[URL-5]

http://www.tdk.gov.tr/index.php?option=com_gts\&arama=gts\&guid=TDK.GTS.5a1de3a 916b0e3.48121548 Erişim Tarihi: 11.05.2017 